\title{
Coordinated changes of HIV-1 Gag and Env during assembly and maturation
}

\author{
Hans-Georg Kräusslich \\ From Frontiers of Retrovirology: Complex retroviruses, retroelements and their hosts \\ Cambridge, UK. 16-18 September 2013
}

Formation of infectious HIV-1 particles involves assembly of Gag polyproteins into immature particles and subsequent assembly of mature capsids following proteolytic disassembly of the Gag shell. Maturation is essential for viral infectivity; it is required for full activity of viral enzymes, for virus uncoating and for efficient membrane fusion. Morphological maturation involves dramatic rearrangements in the interior of the virus, but also leads to coordinated clustering of the low number of Env trimers on the virion surface. Env incorporation is dependent on specific regions in Gag and the C-terminal tail of Env, but appears to be mediated by formation of Env patches larger than the actual assembly site. Here, we will discuss aspects of Gag-dependent Env recruitment and morphological alterations during virion maturation.

Published: 19 September 2013

doi:10.1186/1742-4690-10-S1-O2

Cite this article as: Kräusslich: Coordinated changes of HIV-1 Gag and Env during assembly and maturation. Retrovirology 2013 10(Suppl 1):O2.

Submit your next manuscript to BioMed Central and take full advantage of:

- Convenient online submission

- Thorough peer review

- No space constraints or color figure charges

- Immediate publication on acceptance

- Inclusion in PubMed, CAS, Scopus and Google Scholar

- Research which is freely available for redistribution 